\title{
Space-based retrieval of $\mathrm{NO}_{2}$ over biomass burning regions: quantifying and reducing uncertainties
}

\author{
N. Bousserez ${ }^{1, *}$ \\ ${ }^{1}$ Dalhousie University, Halifax, N.S., Canada \\ *now at: University of Colorado at Boulder, Boulder, Colorado, USA \\ Correspondence to: N. Bousserez (nicolas.bousserez@ colorado.edu)
}

Received: 9 June 2013 - Published in Atmos. Meas. Tech. Discuss.: 22 July 2013

Revised: 30 June 2014 - Accepted: 8 July 2014 - Published: 8 October 2014

\begin{abstract}
The accuracy of space-based nitrogen dioxide $\left(\mathrm{NO}_{2}\right)$ retrievals from solar backscatter radiances critically depends on a priori knowledge of the vertical profiles of $\mathrm{NO}_{2}$ and aerosol optical properties. This information is used to calculate an air mass factor (AMF), which accounts for atmospheric scattering and is used to convert the measured line-of-sight "slant" columns into vertical columns. In this study we investigate the impact of biomass burning emissions on the AMF in order to quantify $\mathrm{NO}_{2}$ retrieval errors in the Ozone Monitoring Instrument (OMI) products over these sources. Sensitivity analyses are conducted using the Linearized Discrete Ordinate Radiative Transfer (LIDORT) model. The $\mathrm{NO}_{2}$ and aerosol profiles are obtained from a 3-D chemistry-transport model (GEOS-Chem), which uses the Fire Locating and Monitoring of Burning Emissions (FLAMBE) daily biomass burning emission inventory. Aircraft in situ data collected during two field campaigns, the Arctic Research of the Composition of the Troposphere from Aircraft and Satellites (ARCTAS) and the Dust and Biomassburning Experiment (DABEX), are used to evaluate the modeled aerosol optical properties and $\mathrm{NO}_{2}$ profiles over Canadian boreal fires and West African savanna fires, respectively. Over both domains, the effect of biomass burning emissions on the AMF through the modified $\mathrm{NO}_{2}$ shape factor can be as high as $-60 \%$. A sensitivity analysis also revealed that the effect of aerosol and shape factor perturbations on the AMF is very sensitive to surface reflectance and clouds. As an illustration, the aerosol correction can range from -20 to $+100 \%$ for different surface reflectances, while the shape factor correction varies from -70 to $-20 \%$. Although previous studies have shown that in clear-sky conditions the effect of aerosols on the AMF was in part implicitly accounted for
\end{abstract}

by the modified cloud parameters, here it is suggested that when clouds are present above a surface layer of scattering aerosols, an explicit aerosol correction would be beneficial to the $\mathrm{NO}_{2}$ retrieval. Finally, a new method that uses slant column information to correct for shape-factor-related AMF error over $\mathrm{NO}_{\mathrm{x}}$ emission sources is proposed, with possible application to near-real-time OMI retrievals.

\section{Introduction}

Nitrogen oxides $\left(\mathrm{NO}_{\mathrm{x}}=\mathrm{NO}_{2}+\mathrm{NO}\right)$ play a key role in tropospheric chemistry by affecting ozone, atmospheric oxidation, and aerosol formation (Logan, 1983). Biomass burning is a significant source of $\mathrm{NO}_{\mathrm{x}}$, which accounts for $\sim 15 \%$ of the global emissions (IPCC, 2007). However this source remains difficult to quantify due to its high spatio-temporal variability (Mebust and Cohen, 2013; Mebust et al., 2011). On the one hand, bottom-up inventories rely on an accurate representation of the different factors controlling $\mathrm{NO}_{\mathrm{x}}$ emission from fires, including the type of vegetation, the burning phase and the combustion efficiency (Wiedinmyer et al., 2006; Andreae and Merlet, 2001). This information is generally only available at local scale, and extrapolations needed for regional or global estimates are therefore associated with uncertainties. On the other hand, top-down estimates from space-based observations allow for the inference of global monthly to daily $\mathrm{NO}_{\mathrm{x}}$ emission inventories (Miyazaki et al., 2012; Lamsal et al., 2011; Martin et al., 2003), with some recent studies having developed capabilities to characterize $\mathrm{NO}_{\mathrm{x}}$ emissions at regional scale and high spatio-temporal resolution (Mebust and Cohen, 2013; Mebust et al., 2011). However, among 
others, these estimates are affected by errors in the retrieved $\mathrm{NO}_{2}$ columns (Boersma et al., 2004; Herron-Thorpe et al., 2010). Since incomplete knowledge of the optical properties of the atmosphere greatly contributes to errors in the inferred $\mathrm{NO}_{2}$ columns, retrievals over biomass burning events are especially challenging due to the emission of large amounts of aerosol with fire-dependent characteristics. Quantifying and reducing errors in the $\mathrm{NO}_{2}$ retrievals is therefore critical to assess and mitigate uncertainties in top-down emission inventories.

Satellite retrievals of $\mathrm{NO}_{2}$ columns from solar backscatter radiations are based on several steps (Richter and Burrows, 2002; Martin et al., 2002). First, a total slant column is inferred from spectral fitting. A stratospheric contribution is then estimated using either a reference slant column over clean areas or a model simulation in order to derive a tropospheric slant column. The tropospheric slant column is subsequently converted into a vertical column using an air mass factor (AMF). The AMF corrects the measurements for the viewing geometry and the atmospheric scattering effects based on a priori knowledge of the $\mathrm{NO}_{2}$ profile shapes, surface characteristics (reflectance, pressure) and atmospheric optical properties. It has been shown that the AMF is the largest source of error in $\mathrm{NO}_{2}$ retrievals (Boersma et al., 2004; Martin et al., 2002). One fundamental issue is related to the fact that the resolution of the input parameters in the AMF calculation is usually much coarser than the satellite pixel area. Recent studies showed that using highresolution terrain information and $\mathrm{NO}_{2}$ profile simulations can result in large differences (more than a factor of 2) in the retrieved $\mathrm{NO}_{2}$ columns compared to products that use a priori data at typical global chemical transport model resolution (Zyrichidou et al., 2013; Heckel et al., 2011; Boersma et al., 2011; Russell et al., 2011; Hains et al., 2010; Zhou et al., 2009). Another approach to tackle the representativeness problem is to use information from the observations themselves, which has been proposed by Lamsal et al. (2008) in the context of top-down estimate of surface $\mathrm{NO}_{2}$ concentrations. In their study, a downscaling technique based on the variability of OMI tropospheric $\mathrm{NO}_{2}$ columns within a coarse model grid cell is used to infer $\mathrm{NO}_{2}$ surface concentration at OMI pixel resolution. Similarly, in this study we will propose a measurement-based correction intended to reduce retrieval errors related to the use of low-resolution $\mathrm{NO}_{2}$ shape profiles and missing sources in the model.

Besides the difficulty of adequately reproducing $\mathrm{NO}_{2}$ shape profiles, biomass burning provides an additional complication by altering the scattering properties of the atmosphere. Previous studies have investigated the impact of aerosols on the AMF using modeled profiles of aerosol characteristics (Leitão et al., 2010; Martin et al., 2003). Differences in the retrieved $\mathrm{NO}_{2}$ columns as large as a factor of 2 were obtained when the aerosol effect was not accounted for in the retrieval. An important finding is that the relative distribution of the aerosol and $\mathrm{NO}_{2}$ profiles plays a key role in determining the aerosol effect on the AMF (Leitão et al., 2010; Chen et al., 2009; Fu et al., 2007). Typically, co-located aerosol and $\mathrm{NO}_{2}$ layers will tend to increase the AMF, while the presence of an aerosol layer above the boundary layer $\mathrm{NO}_{2}$ bulk will decrease the AMF (shielding effect). However, it is still unclear how to account for the aerosol effect, since cloud products used in AMF calculations are also sensitive to aerosols (Boersma et al., 2011, 2004). Although Boersma et al. (2011) found that the modified cloud parameters implicitly account for part of the aerosol effect (underestimation of 10-20\%), it is unclear to which extent their findings are applicable to retrievals with different aerosol and $\mathrm{NO}_{2}$ vertical distribution characteristics. Moreover, the case where meteorological clouds and aerosols are present in the scene has not been studied yet (Leitão et al., 2010).

As a result of all the aforementioned factors, a recent study by Mebust et al. (2011) suggested that there may be a large negative bias of about $50-100 \%$ in the OMI $\mathrm{NO}_{2}$ retrievals over wildfire. Their conclusion was based on the fact that $\mathrm{NO}_{\mathrm{x}}$ emission coefficients derived from combining OMI $\mathrm{NO}_{2}$ columns and MODIS fire radiative power measurement were significantly lower than in previous studies. Further investigation of the properties of $\mathrm{NO}_{2}$ retrievals over fires is therefore critical. Given the high uncertainty in the prior information used, such a study would ideally need to incorporate in situ observations of aerosols and $\mathrm{NO}_{2}$ profiles over different type of fires.

The Arctic Research of the Composition of the Troposphere from Aircraft and Satellites (ARCTAS) and The Dust And Biomass EXperiment (DABEX) experiments provide extensive aircraft in situ measurements of $\mathrm{NO}_{2}$ concentrations and aerosol optical properties over boreal and savanna fires, respectively. ARCTAS-B took place in June-July 2008 with a major emphasis on boreal forest fire influences over Canada (Parrington et al., 2013; Corr et al., 2012; Jacob et al., 2010). DABEX, part of the African Monsoon Multidisciplinary Analysis (AMMA) experiment, took place in January 2006 over West Africa (Johnson et al., 2008a; Capes et al., 2008; Redelsperger et al., 2006). These two campaigns provide an unprecedented data set to evaluate modeled aerosol and $\mathrm{NO}_{2}$ profiles that are used in the AMF calculation over different biomass burning regions. To our knowledge, a comprehensive analysis of $\mathrm{NO}_{2}$ retrievals over biomass burning supported by detailed aerosol and $\mathrm{NO}_{2}$ in situ measurements has not been conducted yet.

In this study, the impact of biomass burning emissions on the AMF is assessed using the the Linearized Discrete Ordinate Radiative Transfer (LIDORT) model (Spurr et al., 2001; Spurr, 2002) combined with aerosol and $\mathrm{NO}_{2}$ profiles from a GEOS-Chem 3-D chemistry transport model (CTM) simulation with daily resolved fire emissions from Fire Locating and Monitoring of Burning Emissions (FLAMBE) (Reid et al., 2009). In Sect. 2, the theoretical basis for the AMF algorithm is introduced. In Sect. 3, a detailed description of 
the ARCTAS-B and DABEX experiments is provided. In Sect. 4 , the modeled aerosol optical properties and $\mathrm{NO}_{2}$ profile shapes are evaluated against the ARCTAS and DABEX observations. In Sects. 5 to 8, the sensitivity of the AMF to biomass burning emissions and its dependence to several retrieval parameters is investigated. Finally, in Sect. 9, an approach based on slant column measurement information to reduce AMF errors associated with $\mathrm{NO}_{2}$ shape factor uncertainties is proposed.

\section{AMF calculation}

The tropospheric AMF is defined as the ratio of the tropospheric slant column, which is the total tropospheric amount of trace gas along an average backscattered path observed by a satellite instrument, to the tropospheric vertical column of this trace gas. Following Palmer et al. (2001), the tropospheric AMF can be expressed as

$\mathrm{AMF}=\mathrm{AMF}_{\mathrm{G}} \int_{0}^{1} \omega(\sigma) S(\sigma) \mathrm{d} \sigma$.

In this equation $\mathrm{AMF}_{\mathrm{G}}$ is the geometric $\mathrm{AMF}$ accounting for the satellite viewing geometry. The term $\sigma$ represents the sigma vertical coordinate of the model, related to the pressure $P$ by $P=\sigma\left(P_{\mathrm{S}}-P_{\mathrm{T}}\right)+P_{\mathrm{T}}$, where $P_{\mathrm{S}}$ and $P_{\mathrm{T}}$ are the pressure at the surface and the top of the troposphere, respectively. $S(\sigma)$ is the shape factor, a dimensionless normalized $\mathrm{NO}_{2}$ vertical profile, and $\omega(\sigma)$ are the scattering weights describing the sensitivity of the backscattered spectrum to the abundance of $\mathrm{NO}_{2}$ at each $\sigma$-level.

The AMF formulation used takes into account cloudcontaminated pixels following the independent pixel approximation, as described in Martin et al. (2002). The cloud fraction and cloud pressure are retrieved from OMI using the $\mathrm{O}_{2}-\mathrm{O}_{2}$ algorithm (Acarreta et al., 2004). Surface reflectivity was obtained from a climatology from OMI at $440 \mathrm{~nm}$ (Kleipool et al., 2008). Scattering weights are calculated using the Linearized Discrete Ordinate Radiative Transfer (LIDORT) model (Spurr et al., 2001; Spurr, 2002). The $\mathrm{NO}_{2}$ shape factors and aerosol optical characteristics are obtained from a GEOS-Chem simulation described in Appendix A.

\section{Observational data set}

\subsection{ARCTAS-B campaign}

The summer ARCTAS-B campaign took place in late June and early July 2008 (Jacob et al., 2010). The primary goal of this experiment was to better understand the factors driving current changes in Arctic atmospheric composition and climate.

The campaign included the DC-8 research aircraft to measure chemical and radiative properties of the atmosphere.
From 26 June to 14 July 2008, the aircraft was based in Cold Lake, Canada $\left(54^{\circ} \mathrm{N}, 110^{\circ} \mathrm{W}\right)$, where it sampled many fresh and aged biomass burning plumes at a wide range of altitudes (Alvarado et al., 2010). The DC-8 included highly sensitive high-frequency (1-10 s) measurements of key ozone precursors $\left(\mathrm{NO}_{\mathrm{y}}, \mathrm{HO}_{\mathrm{x}}, \mathrm{PAN}, \mathrm{HCHO}\right)$ as well as aerosol optical and physical properties. Measurement characteristics for the species considered in this study are summarized Table 1. For a more detailed description of the chemical and optical properties of biomass burning plumes sampled during ARCTASB the reader is referred to Singh et al. (2010) and Alvarado et al. (2010).

\subsection{DABEX campaign}

The African Monsoon Multidisciplinary Analysis (AMMA) is a major international experiment designed to improve our understanding of the West African monsoon (Redelsperger et al., 2006). The Dust And Biomass burning EXperiment (DABEX) was part of the Special Observing Period (SOP) dry season (January-February 2006). It was carried out over West African by the UK Met Office, which used the FAAM BAe-146 aircraft to perform high-quality in situ measurements of the chemical, optical and physical properties of biomass burning and dust aerosols over West Africa. The area sampled covered a narrow domain spanning from western Niger, where mineral dust is predominant, to central Benin, where savanna fires occur.

Physical and optical properties of dust and biomass burning aerosols during DABEX were analyzed in detail in several studies (Johnson et al., 2008a, b; Osborne et al., 2008; Capes et al., 2008). Analysis of fresh biomass burning aerosols was especially challenging due to frequent mixing with mineral dust near the surface. Nevertheless, results show similar aerosol characteristics than previously found during the SAFARI-2000 campaign over southern Africa (Haywood et al., 2003).

Table 2 summarizes the measurement characteristics for the data considered in this study. To complete our model evaluation, we also used aerosol optical depth (AOD) and single scattering albedo (SSA) surface in situ data from the Aerosol Robotic Network (AERONET) network, which consist of sun photometer measurements (Dubovik et al., 2002).

\section{Model evaluation}

The GEOS-Chem 3-D chemistry transport model described in Appendix A is a central tool in our AMF analysis, since it provides the aerosol and $\mathrm{NO}_{2}$ profiles used in the radiative transfer calculation. The GEOS-Chem simulation is performed at a $2^{\circ}$ latitude $\times 2.5^{\circ}$ longitude horizontal grid resolution and uses a global daily biomass burning emission inventory. Aerosol optical properties in GEOS-Chem are simulated following Martin et al. (2003). Here the modeled 
Table 1. DC-8 research payload during ARCTAS-B for the species considered in this study.

\begin{tabular}{llll}
\hline Species, parameters & Method & Investigator & Reference \\
\hline $\mathrm{NO}_{2}$ & TD-LIF & R. Cohen, UC Berkeley & Cleary et al. (2002) \\
Aerosol optical properties & Nephelometer, PSPAP & B. Anderson, NASA LaRC & Anderson and Ogren (1998) \\
Black carbon aerosol & SP2 & Y. Kondo, U. Tokyo & Moteki and Kondo (2008); Moteki et al. (2007)
\end{tabular}

TD-LIF $=$ Thermal dissociation-laser induced fluorescence, $\mathrm{SP} 2=$ Single particle soot photometer

aerosol optical properties and $\mathrm{NO}_{2}$ profiles were evaluated against aircraft in situ measurements from the DABEX and ARCTAS campaigns. For this purpose, model outputs were interpolated along the flight tracks and filtered to retain only observations influenced by biomass burning emissions.

For ARCTAS, measurements impacted by biomass burning emissions were identified by enhancements in $\mathrm{HCN}$ and CO concentrations greater than $20 \%$ of the regional background.

For DABEX, measurements influenced by biomass burning were defined according to Johnson et al. (2008b), who derived the following criteria:

- scattering at $550 \mathrm{~nm}$ (green) $>30 \times 10^{-6} \mathrm{~m}$

- Ångström exponent $>1$.

A model sensitivity simulation was performed to ensure that the selected observations were also associated with biomass burning influences in the model. Mean modeled and observed profiles were subsequently derived by vertically binning the data over the entire ARCTAS $\left(150-80^{\circ} \mathrm{W}, 49-\right.$ $\left.70^{\circ} \mathrm{N}\right)$ and $\operatorname{DABEX}\left(2^{\circ} \mathrm{W}-8^{\circ} \mathrm{E}, 8-20^{\circ} \mathrm{N}\right)$ domains.

Figure 1 shows the observed and simulated shape factor, aerosol extinction coefficient $(440 \mathrm{~nm})$ and SSA $(440 \mathrm{~nm})$ mean profiles during ARCTAS. There is an overall good agreement between the model and the measurements. The $\mathrm{NO}_{2}$ shape factor shows a sharp enhancement near the surface due to fire emissions. Model analyses (not shown) suggest that the gradient observed at the top of the troposphere and not seen in the model is due to an underestimation of lightning $\mathrm{NO}_{\mathrm{x}}$ emissions. Aerosol extinction coefficients also increase in the boundary layer as a result of biomass burning emissions. The shape and magnitude of the extinction is similar in the model and the measurements. The mean SSA profile is also reasonably well reproduced by the model, with relatively homogeneous values of $0.90-0.95$. These observations are consistent with SSA values derived by Reid et al. (2005) over boreal fires using AERONET measurements.

Figure 1 shows the profiles of the shape factor, aerosol extinction coefficient $(440 \mathrm{~nm})$ and aerosol scattering coefficient $(440 \mathrm{~nm})$ from GEOS-Chem and the FAAM BAe146 measurements during DABEX. Since aerosol absorption measurements were available only at $565 \mathrm{~nm}$, the observed extinction at $565 \mathrm{~nm}$ has been scaled to $440 \mathrm{~nm}$ by applying the ratio between the scattering coefficients at 440 and $565 \mathrm{~nm}$. In order to conserve original measurements in the comparison, here the choice has been made to show the scattering coefficient at $440 \mathrm{~nm}$ instead of the SSA. The modeled and observed shape factors show a significant increase near the surface, similar to the one observed over boreal fires. Aerosol extinction and scattering coefficient profile shapes are well reproduced by GEOS-Chem. The model underestimation near the surface may be attributed to representativeness errors given the coarse resolution used. Note that the poor sampling of the boundary layer during DABEX limits confidence in the results near the surface. Aerosol extinction coefficients measured over savanna fires $(\sim 0.4-$ $\left.0.8 \mathrm{~km}^{-1}\right)$ are significantly greater than those observed over boreal fires during ARCTAS $\left(\sim 0.1-0.2 \mathrm{~km}^{-1}\right)$. Again, the boundary layer observations during DABEX are representative of specific fire events rather than average characteristics. Table 3 contains the AOD and SSA columns for GEOSChem and the AERONET measurements at several stations in West Africa. The modeled SSA agrees with observations within 0.02 in average, and the modeled AOD within $23 \%$.

In conclusion, the evaluation of the simulated $\mathrm{NO}_{2}$ profiles and aerosol optical properties over boreal and savanna fires shows that the GEOS-Chem model reproduces reasonably well the observed vertical distributions. In the following, aerosol and $\mathrm{NO}_{2}$ shape profiles simulated by GEOS-Chem are used to calculate the AMF and to analyze its sensitivity to biomass burning emissions.

\section{Impact of biomass burning emissions on the AMF}

Generally the high spatial and temporal variability of fire emissions is not fully resolved in CTMs. This is in part due to representativeness errors owing to the coarse resolution of the model simulations as well as to incomplete knowledge of the different factors influencing fire emissions, such as the vegetation type and the combustion efficiency, as well as the phase of the fires (flaming, smoldering), which can be associated with different $\mathrm{NO}_{\mathrm{x}}$ / aerosol emission ratios (Andreae and Merlet, 2001). Assuming the aerosol effect is at least partially accounted for by the cloud correction, only the impact of biomass burning on the $\mathrm{NO}_{2}$ shape factor is considered here (the aerosol effects are not explicitly accounted for in the AMF). A shape factor correction associated with fire emissions can be defined as the ratio between an AMF that includes biomass burning emissions and an AMF that does not include these emissions: 


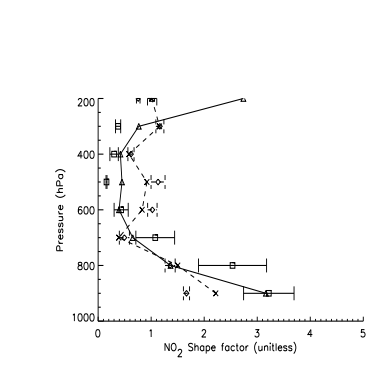

a)

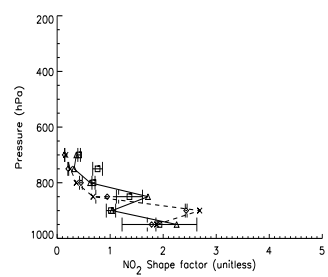

d)

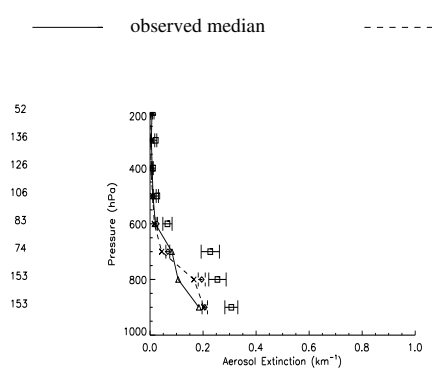

b)

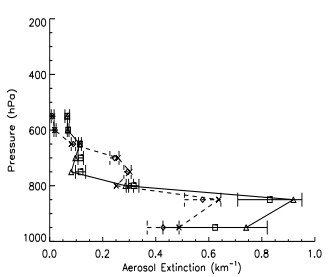

e)

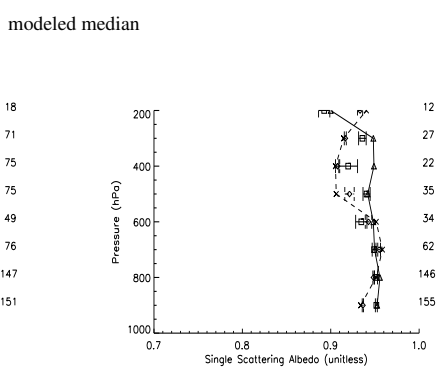

c)

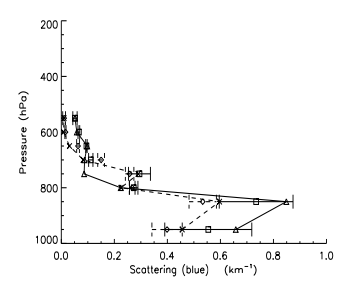

f)

Figure 1. Simulated and observed vertical profiles of $\mathrm{NO}_{2}$ shape factors (a), aerosol extinction coefficient (440 nm) (b), and single scattering albedo $(440 \mathrm{~nm})(\mathbf{c})$ during ARCTAS, and $\mathrm{NO}_{2}$ shape factors $(\mathbf{d})$, aerosol extinction coefficient $(440 \mathrm{~nm})(\mathbf{e})$, and aerosol scattering coefficient $(440 \mathrm{~nm})$ (f) during DABEX. Modeled median values (dashed line) are represented by crosses and observed median values (solid line) by triangles. Modeled mean values are represented by diamonds and observed mean values by square. Bars indicate the standard error of the mean at each altitude level.

Table 2. FAAM BAe-146 research payload during DABEX for the species considered in this study.

\begin{tabular}{lll}
\hline Species, parameters & Instrument & Comment \\
\hline $\mathrm{NO}_{2}$ & TECO 42 & detection limit $<2$ ppbv \\
Aerosol absorption & Radiance Research PSAP & wavelength, $\lambda=0.568$ mum \\
Dry aerosol scattering & TSI 3563 Nephelometer & $\lambda=0.45,0.55,0.70 \mu \mathrm{m}$ \\
\hline
\end{tabular}

$\mathrm{AMF}_{\mathrm{cor}}=\frac{\mathrm{AMF}_{\mathrm{bb}}}{\mathrm{AMF}_{\mathrm{nobb}}}$,

where subscripts on the right-hand side specify if biomass burning emissions are included (bb) or not (nobb) in the AMF calculation.

Figure 2 shows the mean shape factor correction over boreal and savanna fires during ARCTAS and DABEX, respectively. Only OMI scenes with cloud fraction $<5 \%$ have been considered here in order to limit the interference of clouds in the analysis while retaining a statistically significant number of data. The AMF correction ranges from -60 to $0 \%$. Fire emissions reduce the AMF by increasing the $\mathrm{NO}_{2}$ shape factor near the surface (and decreasing it above) where measurement sensitivity is minimum. These results show that $\mathrm{NO}_{2}$ retrievals over fires can underestimate $\mathrm{NO}_{2}$ tropospheric columns by a factor of 2 when some of these sources are missing in the model. This scenario will generally correspond to wildfire events, which are by nature unpredictable and whose emissions are not currently accounted for in realtime retrievals. Note that the AMF correction presented here does not take into account representativeness errors due to the coarse model resolution. This problem will be addressed in Sect. 9.

Also, although here it is assumed that the aerosol effect is implicitly accounted for by the cloud correction algorithm, this assumption has been questioned in a recent study by Leitão et al. (2010) in the case of cloudy scenes. A better understanding of the effect of aerosols on the AMF can help investigate this issue further. This effect needs to be characterized for different retrieval parameters (e.g., SSA, surface reflectance). Similarly, the impact of the modified $\mathrm{NO}_{2}$ shape factor on the AMF is modulated by changes in these parameters.

In the next two sections we study in detail the sensitivity of the AMF to aerosol and $\mathrm{NO}_{2}$ shape factor perturbations for a case representative of the conditions found over savanna fires during the DABEX campaign. 
ARCTAS

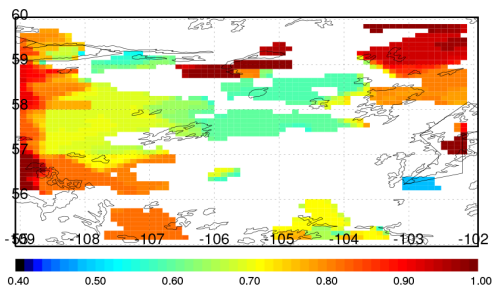

AMF correction
DABEX

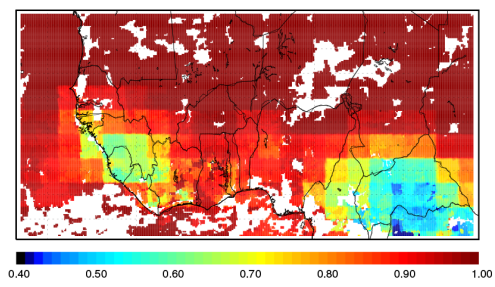

AMF correction

Figure 2. Mean AMF shape factor correction over Canadian fires during ARCTAS (30 June-10 July 2008) (left) and West African fires during DABEX (13 January-2 February 2006) (right). Retrievals with a cloud fraction $>5 \%$ have been excluded.

Table 3. Simulated and observed mean SSA and AOD columns at several AERONET sites during DABEX.

\begin{tabular}{|c|c|c|}
\hline & SSA & AOD \\
\hline \multicolumn{3}{|c|}{ Banizoumbou $\left(13^{\circ} \mathrm{N}, 2^{\circ} \mathrm{E}\right)$} \\
\hline AERONET & 0.84 & 0.75 \\
\hline $\mathrm{GC}$ & 0.84 & 0.63 \\
\hline \multicolumn{3}{|c|}{ Djougou $\left(9^{\circ} \mathrm{N}, 1^{\circ} \mathrm{E}\right)$} \\
\hline AERONET & 0.82 & 1.05 \\
\hline GC & 0.84 & 1.19 \\
\hline \multicolumn{3}{|c|}{ IER-Cinzana $\left(13^{\circ} \mathrm{N}, 5^{\circ} \mathrm{W}\right)$} \\
\hline AERONET & 0.83 & 0.65 \\
\hline GC & 0.85 & 0.61 \\
\hline \multicolumn{3}{|c|}{ Ilorin $\left(8^{\circ} \mathrm{N}, 4^{\circ} \mathrm{E}\right)$} \\
\hline AERONET & 0.86 & 1.37 \\
\hline GC & 0.89 & 0.80 \\
\hline \multicolumn{3}{|c|}{ DMN-Maine Soroa $\left(13^{\circ} \mathrm{N}, 12^{\circ} \mathrm{E}\right)$} \\
\hline AERONET & 0.88 & 0.80 \\
\hline $\mathrm{GC}$ & 0.82 & 1.23 \\
\hline \multicolumn{3}{|c|}{$\operatorname{Dakar}\left(14^{\circ} \mathrm{N}, 16^{\circ} \mathrm{W}\right)$} \\
\hline AERONET & 0.83 & 0.84 \\
\hline GC & 0.85 & 0.95 \\
\hline
\end{tabular}

\section{Aerosol correction factor sensitivity analysis}

In this section, we assess the influence of aerosols on the AMF and its dependence to aerosol characteristics (optical properties, profile shape) as well as key retrieval parameters (satellite viewing geometry, surface reflectance, clouds). A sensitivity analysis is conducted using a reference profile for aerosols and $\mathrm{NO}_{2}$ from the DABEX GEOS-Chem simulation evaluated in Sect. 4. The reference solar zenith angle (SZA), SSA and surface reflectance are $40^{\circ}, 0.91$, and 0.03 , respectively. In the sensitivity experiment, each parameter varies while others are kept constant. Since the model horizontal resolution $\left(2^{\circ} \times 2.5^{\circ}\right)$ is much coarser than the OMI's, and in order to minimize the representativeness error above biomass burning sources, the grid cell associated with highest emissions during the DABEX period has been selected. Figure 3 shows the corresponding simulated $\mathrm{NO}_{2}$ and aerosol profiles at OMI overpass time (13:30 p.m., local time). The presence of an elevated aerosol layer is consistent with previous observations and analyses over African biomass burning regions (Jury and Winter, 2010; Anderson et al., 1996; Johnson et al., 2008b). During DABEX, this pattern has been shown to be due to the uplift of biomass burning aerosols by the Harmattan front (Haywood et al., 2008).

The aerosol correction factor is defined as the ratio between an AMF that includes aerosol effects and an AMF that does not include them. The sensitivity of the aerosol correction factor to aerosol profile shape has been evaluated by comparing the correction with and without the elevated aerosol layer, as represented Fig. 3. As a result of the shielding effect, the aerosol correction factor decreases from +20 to $-30 \%$ in the presence of the elevated aerosol layer.

Figure 4 shows the influence of SSA, SZA and surface reflectance on the aerosol correction factor for the two types of profile considered. For each of these parameters, the sensitivity of the aerosol correction factor is similar whether or not the elevated aerosol layer is included. The AMF being a vertical integration of the scattering coefficients weighted by the $\mathrm{NO}_{2}$ shape factor, its sensitivity is driven by optical properties near the surface where the $\mathrm{NO}_{2}$ shape factor peaks, which explains the similarities observed.

The aerosol correction factor is very sensitive to surface reflectance. We observe an exponential decay, which reflects the competing effects of the measurement sensitivity increase due to scattering above the aerosol layer and the shielding effect below it. We see that the relative impact of the shielding effect increases quickly with surface reflectance with an asymptotic limit for surface reflectance $>0.1$. For surface only aerosols, the correction varies from $+100 \%$ for very low surface reflectance to $-20 \%$ for surface reflectance $>0.1$. Our results are consistent with previous findings by Leitão et al. (2010) for similar $\mathrm{NO}_{2}$ and aerosol 

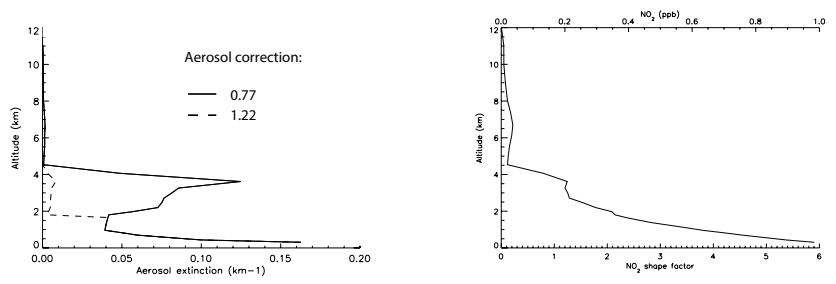

Figure 3. Left: GEOS-Chem aerosol extinction coefficients profile with (solid line) and without (dashed line) the elevated aerosol layer for a single grid cell over West African fires at OMI overpass time (13:30 LT). The aerosol correction factor values corresponding to each type of aerosol profile are reported in the figure. Right: GEOSChem $\mathrm{NO}_{2}$ profile shape for the same grid cell.

profile configurations and fine aerosol particles (more representative of savanna fires). Note that, as their results show, the decrease of the aerosol correction with surface reflectance is faster when coarse aerosol particles are considered (more representative of forest fires). When compared to the reference case, the change in the aerosol correction due to surface reflectance variations ranges from -40 to $+40 \%$. Russel et al. (2011) report similar changes in $\mathrm{OMI} \mathrm{NO}_{2}$ column retrievals when using a high-resolution surface albedo product over California compared to the low-resolution standard product. Local changes of -20 to $+10 \%$ in retrieved $\mathrm{NO}_{2}$ columns are also obtained using a high-resolution surface albedo product in Boersma et al. (2011).

A linear increase of the aerosol correction factor with SSA is observed, while the viewing geometry (SZA) has negligible impact on the correction, which is consistent with findings by Leitão et al. (2010) over urban areas.

The impact of emission intensity on the aerosol correction factor has been assessed by rescaling the aerosol and $\mathrm{NO}_{2}$ concentrations within a $0-1 \mathrm{~km}$ surface layer. Figure $4 \mathrm{~d}$ shows that the effect of aerosols on the AMF is almost insensitive to emission intensity. This reflects the balance between the AMF increase caused by aerosol scattering effects and the AMF decrease due to $\mathrm{NO}_{2}$ shape factor enhancements at the surface. A direct consequence is that the aerosol correction factor will be only weakly impacted by emission representativeness errors within one model grid cell as long as the aerosol $/ \mathrm{NO}_{2}$ emission factors are homogeneous inside that domain.

The presence of clouds above the aerosol layer can modify the aerosol correction factor through its shielding effect. Figure 5 shows the aerosol correction factor as a function of cloud fraction for different AODs, and for the two aerosol profiles considered in Fig. 3. Here the cloud top pressure was set to $460 \mathrm{hPa}$, which corresponds to clouds above the elevated aerosol layer. For any AOD value, the aerosol correction factor increases linearly with cloud fraction. This reflects the higher relative impact of aerosol scattering on the AMF for higher shielding effects, due to the aerosol correction being a ratio of smaller AMFs. Note that increasing the
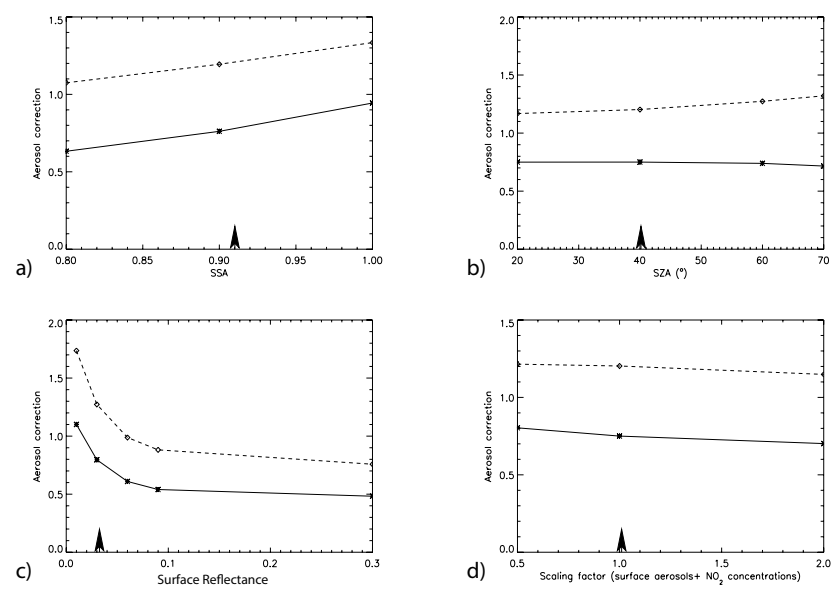

Figure 4. Aerosol correction factor sensitivity to (a) single scattering albedo, (b) solar zenithal angle, (c) surface reflectance, and (d) emissions (aerosol and $\mathrm{NO}_{2}$ surface concentration rescaling). Solid and dashed lines correspond to the case with and without the elevated aerosol layer, respectively. For each parameter, the arrow indicates the value corresponding to the reference case.

optical thickness of the elevated aerosol layer does not modify the sensitivity of the aerosol correction factor to cloud fraction. This is expected since an elevated aerosol layer will essentially play the same role as an increase in cloud fraction in the retrieval algorithm. However, in the case where $\mathrm{NO}_{2}$ and aerosols are co-located near the surface, the aerosol correction factor sensitivity to cloud radiance fraction increases with AOD. As a result, for an AODs $>1$, which is commonly measured over biomass burning events (Gogoi et al., 2013), we see from Fig. 5 that the aerosol correction can vary from +20 to $+100 \%$ between clear-sky and cloudy (cloud fraction of $20 \%$ ) conditions. As discussed in Boersma et al. (2011, 2004), it is important to realize that in real retrieval conditions aerosols will impact the retrieved clouds parameters used in the AMF calculation. This important aspect is discussed in the next section.

\section{Do clouds implicitly account for aerosol effects?}

Since aerosols impact the retrieved cloud parameters in the UV-Vis, correcting AMFs for aerosols cannot be decoupled from correcting cloud retrieval schemes for aerosols. In Boersma et al. $(2011,2004)$, it is shown that the effect of aerosols on the AMF is partly accounted for through the modified cloud parameters for clear-sky scenes and exponentially decreasing shape profiles for aerosols and $\mathrm{NO}_{2}$. However, as Leitão et al. (2010) explained, if clouds are present above a surface layer of scattering aerosols, the retrieved cloud fraction will be enhanced, while the cloud pressure will remain unchanged. Therefore, instead of increasing the AMF and implicitly correcting for aerosol effects, the modified cloud fraction will in fact decrease the AMF. In this case, 

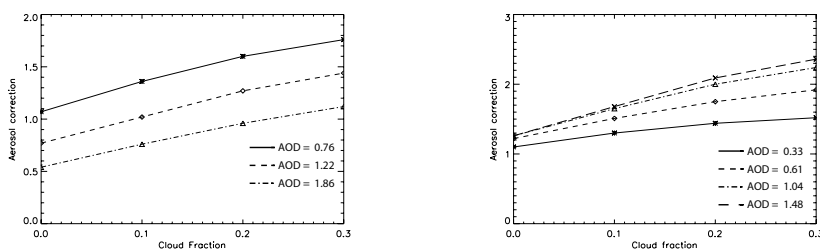

Figure 5. Aerosol correction factor sensitivity to cloud fraction for different AODs. Left: case with an elevated aerosol layer. Right: case with a surface-only aerosol layer. Different AODs were obtained by rescaling either the elevated aerosol layer (left panel) or the surface aerosol layer (right panel).

explicitly accounting for the aerosol scattering effect would counterbalance the additional shielding effect from clouds and may therefore improve the retrieval. This is illustrated by the following relationships, valid for cloudy retrievals including a surface layer of scattering aerosols:

$\mathrm{AMF}^{\delta \text { cloud }}<\mathrm{AMF}_{\text {aerosol }}^{\delta \text { cloud }} \leq \mathrm{AMF}_{\text {aerosol }}$,

where "aerosol" indicates that an explicit aerosol correction is used, and $\delta$ cloud represents the perturbation of cloud fraction by aerosols. Here we see that the AMF using an explicit aerosol correction factor $\left(\mathrm{AMF}_{\text {aerosol }}^{\delta \text { cloud }}\right)$ yields a better approximation to the true $\mathrm{AMF}\left(\mathrm{AMF}_{\text {aerosol }}\right)$. The fact that it is theoretically possible to reproduce the true AMF (weak inequality) follows from our previous result that an increase in cloud fraction induces an increase in the aerosol correction factor. Therefore, this suggests that in the presence of clouds and surface scattering aerosols, the aerosol effects should be explicitly accounted for in the AMF calculation. On the other hand, as explained in Leitão et al. (2010), if the surface aerosols are very absorbing, the retrieved cloud fraction will be reduced, which cannot compensate for the shielding effect of aerosol absorption.

\section{Shape factor correction sensitivity analysis}

The impact of biomass burning emissions on the AMF through the modified $\mathrm{NO}_{2}$ shape factors is also altered by changes in other retrieval parameters. Figure 6 shows the sensitivity of the shape factor correction to cloud fraction and surface reflectance. The shape factor correction decreases almost linearly with cloud fraction. The shape-factor-related AMF errors vary from -60 to $-80 \%$ between clear-sky conditions and a cloud fraction of $30 \%$.

Similarly to the aerosol correction factor, the shape factor correction is highly sensitive to surface reflectance at low values $(0-0.1)$. As an illustration, for the surface reflectance associated with our reference case over West African fires (0.03), the AMF error associated with missing fire sources can be as high as $60 \%$, but only $20 \%$ for a surface reflectance of 0.3 . This highlights the need for high spatial resolution surface albedo climatology in the AMF calculation,
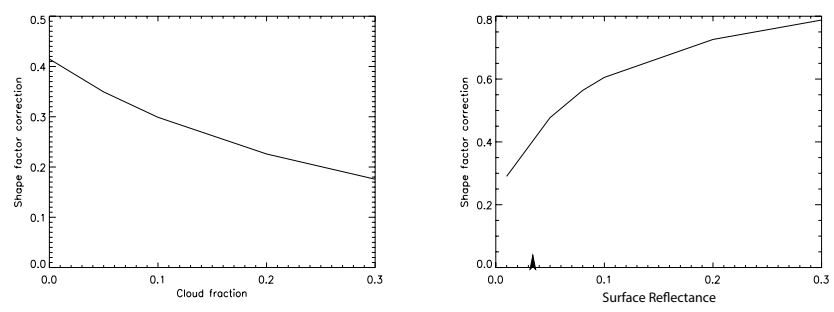

Figure 6. Shape factor correction sensitivity to cloud fraction (left) and surface reflectance (right). The arrow indicates the surface reflectance value corresponding to the reference case.

as has been recently implemented in an improved $\mathrm{OMI} \mathrm{NO}_{2}$ product by Boersma et al. (2011). This latter product uses monthly surface albedo climatology based on OMI data at $0.5^{\circ} \times 0.5^{\circ}$. Given the very high sensitivity of the shape factor correction to surface reflectance, the much-improved product proposed by Russell et al. (2011), which, consisting in weekly $0.05^{\circ} \times 0.05^{\circ}$ surface albedo data based on MODIS observations, would certainly be a key improvement to $\mathrm{NO}_{2}$ retrievals over biomass burning areas.

\section{Measurement-based shape factor correction}

It has been recently shown that uncertainties in the simulated $\mathrm{NO}_{2}$ shape factors and in surface albedo input data are the dominant sources of error in the AMF (Heckel et al., 2011). Of concern is that current operational $\mathrm{OMI} \mathrm{NO}_{2}$ retrievals cannot fully represent the true spatial and temporal variation of $\mathrm{NO}_{2}$ profiles needed for accurate retrievals over fast-changing sources (e.g., biomass burning). For instance, the NASA standard $\mathrm{OMI} \mathrm{NO}_{2}$ product currently uses geographically gridded monthly average $\mathrm{NO}_{2}$ profiles from GMI CTM multi annual (2005-2007) simulations (Bucsela et al., 2013). Here we investigate a method to infer shape factor corrections using measurement information. As explained in Sect. 2, measurement information is contained in the slant columns. Over high $\mathrm{NO}_{\mathrm{x}}$ sources like fires, most of the $\mathrm{NO}_{2}$ column will be concentrated in the boundary layer (Lamsal et al., 2008; Bucsela et al., 2008). Local variability of the slant columns will therefore be primarily affected by variability of the lower part of the $\mathrm{NO}_{2}$ profile.

Here we use this property to establish a relationship between the shape factor correction and the associated slant column perturbation, defined as the relative increase of the slant column with respect to a case without biomass burning emissions. Slant columns and shape factor corrections are computed using a pseudo-retrieval experiment, in which OMI $\mathrm{NO}_{2}$ averaging kernels are applied to the GEOS-Chem $\mathrm{NO}_{2}$ profiles (Eskes and Boersma, 2003). Two GEOS-Chem simulations, one using daily biomass burning emissions $\left(\mathrm{BB}_{\text {sim }}\right)$, and one with biomass burning emissions turned off 
$\left(\mathrm{NOBB}_{\text {sim }}\right)$ are used to generate three types of pseudo $\mathrm{NO}_{2}$ retrievals:

- A, of $\mathrm{BB}_{\text {sim }}$ using $\mathrm{NO}_{2}$ shape factors from $\mathrm{NOBB}_{\text {sim }}$

- B, of $\mathrm{NOBB}_{\text {sim }}$ using $\mathrm{NO}_{2}$ shape factors from $\mathrm{NOBB}_{\text {sim }}$

- $\mathrm{C}$, of $\mathrm{BB}_{\text {sim }}$ using $\mathrm{NO}_{2}$ shape factors from $\mathrm{BB}_{\text {sim }}$.

Note that using a perfect shape factor in $\mathrm{B}$ and $\mathrm{C}$ (the one corresponding to the column retrieved) results in $\mathrm{B}$ and $\mathrm{C}$ being the actual GEOS-Chem columns.

We further define the following:

- $\Delta \mathrm{NO}_{2}=\frac{\mathrm{A}-\mathrm{B}}{\mathrm{B}}$, the relative $\mathrm{NO}_{2}$ column increase compared to the case without biomass burning

- $\mathrm{NO}_{2}$ correction factor $=\frac{\mathrm{C}}{\mathrm{A}}$.

Since the same AMF is used in $\mathrm{A}$ and $\mathrm{B}\left(\mathrm{AMF}_{\mathrm{A}}=\mathrm{AMF}_{\mathrm{B}}\right)$, the dependence of $\Delta \mathrm{NO}_{2}$ to measurement information can be made explicit by rewriting

$$
\begin{aligned}
\Delta \mathrm{NO}_{2} & =\frac{\frac{\text { Slt }_{\mathrm{A}}}{\mathrm{AMF}_{\mathrm{A}}}-\frac{\mathrm{Slt}_{\mathrm{B}}}{\mathrm{AMF}_{\mathrm{B}}}}{\frac{\text { Slt }_{\mathrm{B}}}{\mathrm{AMF}_{\mathrm{B}}}} \\
& =\frac{\text { Slt }_{\mathrm{A}}-\mathrm{Slt}_{\mathrm{B}}}{\mathrm{Slt}_{\mathrm{B}}},
\end{aligned}
$$

where "Slt" represents the slant column.

Pseudo $\mathrm{NO}_{2}$ observations were generated at $\mathrm{OMI}$ overpass time and with a horizontal resolution of $0.1^{\circ} \times 0.1^{\circ}$ for the entire DABEX period (January 2006). Figure 7 shows the relationship between $\triangle \mathrm{NO}_{2}$ and the $\mathrm{NO}_{2}$ correction factor over West African fires during DABEX. The correction factor increases with $\Delta \mathrm{NO}_{2}$ with a "saturation effect" for $\Delta \mathrm{NO}_{2}>4$, where the $\mathrm{NO}_{2}$ correction is almost constant $(=3)$. Further increasing $\mathrm{NO}_{\mathrm{x}}$ emissions above this threshold does not change the shape factor since almost the totality of the $\mathrm{NO}_{2}$ column is already concentrated in the boundary layer. The relationship between the $\mathrm{NO}_{2}$ correction factor and $\Delta \mathrm{NO}_{2}$ can be well approximated by the following logarithmic fit:

$\mathrm{NO}_{2}$ correction factor $=\log \left(3.4 \Delta \mathrm{NO}_{2}+2.2\right)$.

The above formula can be applied to real retrievals by replacing the pseudo slant columns Slt $\mathrm{A}_{\mathrm{A}}$ in Eq. (4) by the retrieved $\mathrm{NO}_{2}$ slant column, and assuming the pseudo slant column Slt $\mathrm{B}$ is a good approximation of what would be the retrieved slant column without the fire source. The standard deviations of the $\mathrm{NO}_{2}$ correction in Fig. 7 can be interpreted as the errors associated with the logarithmic fit approximation (Eq. 5). Although large standard deviations are observed, one sees that they are all significantly smaller than the mean $\mathrm{NO}_{2}$ correction itself. Using this measurement-based correction should therefore reduce $\mathrm{NO}_{2}$ retrieval errors over fires.

Although this correction has been derived for retrievals over West African fire sources, it could easily be extended to other regions and sources. In an operational near-real-time

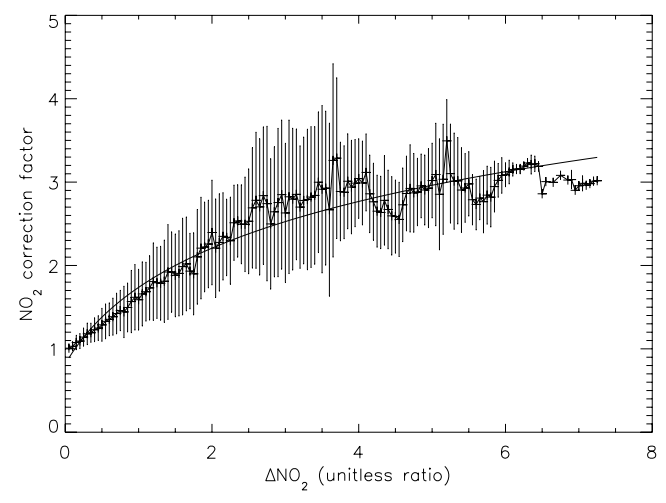

Figure 7. Relationship between the $\mathrm{NO}_{2}$ correction factor and $\Delta \mathrm{NO}_{2}$. Vertical bars represent the standard deviation of the $\mathrm{NO}_{2}$ correction factor within each $\Delta \mathrm{NO}_{2}$ bin. The solid black line represents the logarithmic fit to the curve.

retrieval setting, $\Delta \mathrm{NO}_{2}$ in Eq. (5) can be obtained using a "clean" $\mathrm{NO}_{2}$ profile to derive $\mathrm{Slt}_{\mathrm{B}}$ (reference "clean" slant column) and A. For instance, the reference $\mathrm{NO}_{2}$ profile can be taken from a model simulation without $\mathrm{NO}_{\mathrm{x}}$ emissions. Note that the availability of the retrieval averaging kernels is necessary in order to apply the proposed methodology.

This measurement-based correction is intended to reduce uncertainties related to both representativeness errors and misrepresentation of the location and time of $\mathrm{NO}_{\mathrm{x}}$ emissions in model simulations. Due to the lack of aircraft measurements in the boundary layer during DABEX, our approach cannot be rigorously evaluated using in situ-derived $\mathrm{NO}_{2}$ columns. However, a comparison between $\mathrm{OMI} \mathrm{NO}_{2}$ retrievals using the GEOS-Chem $\mathrm{NO}_{2}$ shape profiles at $2^{\circ} \times$ $2.5^{\circ}$ resolution and the corrected $\mathrm{OMI} \mathrm{NO}_{2}$ retrievals proposed here showed an increase in the $\mathrm{NO}_{2}$ columns of up to $40 \%$ over West African fires (not shown). This is consistent with the changes in retrieved $\mathrm{NO}_{2}$ columns over polluted areas found in Russell et al. (2011) when using highresolution $\mathrm{NO}_{2}$ profiles. A study using in situ data from previous aircraft campaigns (e.g., INTEX-A, INTEX-B, PAVE) (see also more recently Oetjen et al., 2013) as well as from ground-based measurements of $\mathrm{NO}_{2}$ columns (Ma et al., 2013; Rivera et al., 2013; Irie et al., 2012) would allow for a proper evaluation of the robustness of the above formula for different retrieval conditions (biomass burning, urban or remote areas) as well as to better characterize errors.

\section{Conclusions}

In this study, the sensitivity of the air mass factor (AMF) to biomass burning emissions is analyzed in order to better characterize and understand $\mathrm{NO}_{2}$ retrieval uncertainties over fire areas. The radiative transfer model (LIDORT), used to calculate the AMF, can treat both aerosols and clouds effects. Aerosols and $\mathrm{NO}_{2}$ profiles are obtained from a CTM 
simulation (GEOS-Chem) which uses daily resolved biomass burning emissions (FLAMBE). The simulated aerosol optical properties and $\mathrm{NO}_{2}$ profiles were evaluated over Canadian and West African fires using aircraft in situ measurements from the ARCTAS-B 2008 and DABEX 2006 campaigns, respectively.

In clear-sky conditions (cloud fraction $<5 \%$ ), the effect of biomass burning emissions on the AMF through the modified $\mathrm{NO}_{2}$ shape factor ranges from -60 to $0 \%$ over both boreal and savanna fires. These values provide an estimate of the AMF errors associated with $\mathrm{NO}_{2}$ shape factor uncertainties due to missing fire sources in the model, but representativeness errors associated with low-resolution $\mathrm{NO}_{2}$ shape profiles can further enhance these errors. The influence of several retrieval parameters (surface reflectance, clouds, viewing geometry) on the AMF sensitivity to aerosols and shape factors was also analyzed. Both aerosol and shape factor effects are very sensitive to surface reflectance. As an illustration, the aerosol correction can range from -20 to $+100 \%$ for different surface reflectances, while the shape factor correction varies from -70 to $-20 \%$. Using highly spatially resolved surface reflectance data is therefore critical to mitigate $\mathrm{NO}_{2}$ retrieval errors over biomass burning areas. It was found that the intensity of fire emissions does not significantly impact the effect of aerosol for a given $\mathrm{NO}_{2}$ / aerosols emission ratio. This suggests that emissions-related representativeness errors may be weak when modeling the aerosol effects. It was found that the impact of biomass burning emissions on the AMF is also very sensitive to clouds. The aerosol and shape factor corrections can vary from +20 to $+100 \%$ and -60 to $-80 \%$, respectively, when a cloud fraction of $20 \%$ is added to the scene.
Since the OMI clouds retrieval is sensitive to aerosols, previous studies suggested that the aerosol effect on the AMF was implicitly accounted for through the modified cloud parameters. A previous analysis by Leitão et al. (2010) and results from our sensitivity experiment suggest that when clouds are present above a scattering aerosols layer, explicitly taking aerosol effects into account should improve the AMF calculation. More investigations based on sensitivity experiments simulating the effect of aerosols on the cloud retrieval would be necessary to better understand in what cases an explicit aerosol correction would be beneficial to the retrieval.

Finally, a new method has been proposed to reduce $\mathrm{NO}_{2}$ retrieval errors associated with misrepresentations of the $\mathrm{NO}_{2}$ shape profile in the AMF calculation. The approach is based on the local sensitivity of the slant column to $\mathrm{NO}_{2}$ sources. Using a pseudo-retrieval analysis, a relationship between the AMF shape factor correction and the associated slant column perturbation was established. Although this measurement-based correction has been derived over West African fires, it could be extended to any type of $\mathrm{NO}_{\mathrm{x}}$ source. In practice it requires only the retrieval averaging kernels information as well as a "clean" $\mathrm{NO}_{2}$ reference profile, which can be obtained from a model simulation. Future studies using in situ-derived $\mathrm{NO}_{2}$ columns over urban and biomass burning regions would allow for a proper evaluation of the method and would help assess its relevance for existing operational $\mathrm{OMI} \mathrm{NO}_{2}$ retrievals. 


\section{Appendix A: GEOS-Chem simulations}

GEOS-Chem is a global 3-D chemical transport model driven by assimilated meteorological observations from the Goddard Earth Observing System (GEOS) of the NASA Global Modeling and Assimilation Office (GMAO) (www. geos-chem.org; Bey et al., 2001). We use the GEOS-5 meteorological data regridded to $2^{\circ}$ latitude $\times 2.5^{\circ}$ longitude, with 47 vertical layers. For both the DABEX and ARCTASB period we use the NRT-ARCTAS GEOS-Chem simulation, which was originally developed in support of the ARCTAS mission and is based on GEOS-Chem v8-01-01 with minor modifications (Mao et al., 2010). The simulation includes ozone-NOx-HOx-VOC-aerosol chemistry as described in Park et al. (2005).

A daily biomass burning emission inventory at $1^{\circ} \times 1^{\circ}$ resolution obtained from Fire Locating and Monitoring of Burning Emissions (FLAMBE) (Reid et al., 2009) is used to capture the high spatial and temporal variability of fire emissions. The FLAMBE product is constrained by Geostationary Operational Environmental Satellite (GOES) and
Moderate Resolution Imaging Spectrometer (MODIS) fires count data and provides daily global smoke and carbon emissions. Emissions for black carbon and organic carbon species in GEOS-Chem are obtained by applying emission factors to the FLAMBE smoke emissions, while emissions for other species, including $\mathrm{NO}_{\mathrm{x}}$, are derived by applying emission factors to the FLAMBE carbon emissions. Emission factors are those proposed by Andreae and Merlet (2001). Further information about the biomass burning emissions in the model can be found in Fisher et al. (2010).

Dust aerosol concentrations can be significant over West Africa due to transport from the Sahara. The mineral dust module in GEOS-Chem simulates the mobilization of dust from the earth's surface, gravitational settling, and wet and dry deposition as described in Fairlie et al. (2007).

For our ARCTAS simulation, a $70 \%$ decrease of carbon emissions and a $60 \%$ decrease of smoke emissions in the FLAMBE inventory, as well as the use of an extra-tropical forest fires $\mathrm{NO}_{\mathrm{x}}$ emission factor of $0.42 \mathrm{~g} \mathrm{NO}(\mathrm{kg} \mathrm{DM})^{-1}$ (Alvarado et al., 2010) were required in order to match the aircraft in situ observations. 
Acknowledgements. This work was supported by the Canadian Foundation for Climate and Atmospheric Sciences. Nicolas Bousserez would also like to acknowledge support from NASA grant NNX09AN77G.

Edited by: H. Worden

\section{References}

Acarreta, J., De Haan, J., and Stammes, P.: Cloud pressure retrieval using the $\mathrm{O}_{2}-\mathrm{O}_{2}$ absorption band at $477 \mathrm{~nm}$, J. Geophys. Res.Atmos., 109, D05204, doi:10.1029/2003JD003915, 2004.

Alvarado, M. J., Logan, J. A., Mao, J., Apel, E., Riemer, D., Blake, D., Cohen, R. C., Min, K.-E., Perring, A. E., Browne, E. C., Wooldridge, P. J., Diskin, G. S., Sachse, G. W., Fuelberg, H., Sessions, W. R., Harrigan, D. L., Huey, G., Liao, J., Case-Hanks, A., Jimenez, J. L., Cubison, M. J., Vay, S. A., Weinheimer, A. J., Knapp, D. J., Montzka, D. D., Flocke, F. M., Pollack, I. B., Wennberg, P. O., Kurten, A., Crounse, J., Clair, J. M. St., Wisthaler, A., Mikoviny, T., Yantosca, R. M., Carouge, C. C., and Le Sager, P.: Nitrogen oxides and PAN in plumes from boreal fires during ARCTAS-B and their impact on ozone: an integrated analysis of aircraft and satellite observations, Atmos. Chem. Phys., 10, 9739-9760, doi:10.5194/acp-10-9739-2010, 2010.

Anderson, B. E., Grant, W. B., Gregory, G. L., Browell, E. V., Collins Jr., J. E., Sachse, G. W., Bagwell, D. R., Hudgins, C. H., Blake, D. R., and Blake, N. J.: Aerosols from biomass burning over the tropical South Atlantic region: Distributions and impacts, J. Geophys. Res., 101, 24117-24137, doi:10.1029/96JD00717, 1996.

Anderson, T. L. and Ogren, J. A.: Determining aerosol radiative properties using the TSI 3563 integrating nephelometer, Aerosol Sci. Technol., 29, 57-69, 1998.

Andreae, M. O. and Merlet, P.: Emission of trace gases and aerosols from biomass burning, Global Biogeochem. Cy., 15, 955-966, 2001.

Bey, I., Jacob, D., Yantosca, R., Logan, J., Field, B., Fiore, A., Li, Q., Liu, H., Mickley, L., and Schultz, M.: Global modeling of tropospheric chemistry with assimilated meteorology: Model description and evaluation, J. Geophys. Res.-Atmos., 106, 2307323095, doi:10.1029/2001JD000807, 2001.

Boersma, K. F., Eskes, H., and Brinksma, E.: Error analysis for tropospheric $\mathrm{NO}_{2}$ retrieval from space, J. Geophys. Res.-Atmos., 109, D04311, doi:10.1029/2003JD003962, 2004.

Boersma, K. F., Eskes, H. J., Dirksen, R. J., van der A, R. J., Veefkind, J. P., Stammes, P., Huijnen, V., Kleipool, Q. L., Sneep, M., Claas, J., Leitão, J., Richter, A., Zhou, Y., and Brunner, D.: An improved tropospheric $\mathrm{NO}_{2}$ column retrieval algorithm for the Ozone Monitoring Instrument, Atmos. Meas. Tech., 4, 19051928, doi:10.5194/amt-4-1905-2011, 2011.

Bucsela, E. J., Perring, A. E., Cohen, R. C., Boersma, K. F., Celarier, E. A., Gleason, J. F., Wenig, M. O., Bertram, T. H., Wooldridge, P. J., Dirksen, R., and Veefkind, J. P.: Comparison of tropospheric $\mathrm{NO}_{2}$ from in situ aircraft measurements with near-real-time and standard product data from OMI, J. Geophys. Res., 113, D16S31, doi:10.1029/2007JD008838, 2008.

Bucsela, E. J., Krotkov, N. A., Celarier, E. A., Lamsal, L. N., Swartz, W. H., Bhartia, P. K., Boersma, K. F., Veefkind, J. P., Gleason, J. F., and Pickering, K. E.: A new stratospheric and tropospheric $\mathrm{NO}_{2}$ retrieval algorithm for nadir-viewing satellite instruments: applications to OMI, Atmos. Meas. Tech., 6, 26072626, doi:10.5194/amt-6-2607-2013, 2013.

Capes, G., Johnson, B., McFiggans, G., Williams, P. I., Haywood, J., and Coe, H.: Aging of biomass burning aerosols over West Africa: Aircraft measurements of chemical composition, microphysical properties, and emission ratios, J. Geophys. Res.Atmos., 113, D00C15, doi:10.1029/2008JD009845, 2008.

Chen, D., Zhou, B., Beirle, S., Chen, L. M., and Wagner, T.: Tropospheric $\mathrm{NO}_{2}$ column densities deduced from zenith-sky DOAS measurements in Shanghai, China, and their application to satellite validation, Atmos. Chem. Phys., 9, 3641-3662, doi:10.5194/acp-9-3641-2009, 2009.

Cleary, P. A., Wooldridge, P. J., and Cohen, R. C.: Laser-induced fluorescence detection of atmospheric $\mathrm{NO}_{2}$ with a commercial diode laser and a supersonic expansion, Applied Optics, 41, 6950-6956, 2002.

Corr, C. A., Hall, S. R., Ullmann, K., Anderson, B. E., Beyersdorf, A. J., Thornhill, K. L., Cubison, M. J., Jimenez, J. L., Wisthaler, A., and Dibb, J. E.: Spectral absorption of biomass burning aerosol determined from retrieved single scattering albedo during ARCTAS, Atmos. Chem. Phys., 12, 10505-10518, doi:10.5194/acp-12-10505-2012, 2012.

Dubovik, O., Holben, B., Eck, T., Smirnov, A., Kaufman, Y., King, M., Tanre, D., and Slutsker, I.: Variability of absorption and optical properties of key aerosol types observed in worldwide locations, J. Atmos. Sci., 59, 590-608, 2002.

Eskes, H. J. and Boersma, K. F.: Averaging kernels for DOAS totalcolumn satellite retrievals, Atmos. Chem. Phys., 3, 1285-1291, doi:10.5194/acp-3-1285-2003, 2003.

Fairlie, T. D., Jacob, D. J., and Park, R. J.: The impact of transpacific transport of mineral dust in the United States, Atmos. Environ., 41, 1251-1266, doi:10.1016/j.atmosenv.2006.09.048, 2007.

Fisher, J. A., Jacob, D. J., Purdy, M. T., Kopacz, M., Le Sager, P., Carouge, C., Holmes, C. D., Yantosca, R. M., Batchelor, R. L., Strong, K., Diskin, G. S., Fuelberg, H. E., Holloway, J. S., Hyer, E. J., McMillan, W. W., Warner, J., Streets, D. G., Zhang, Q., Wang, Y., and Wu, S.: Source attribution and interannual variability of Arctic pollution in spring constrained by aircraft (ARCTAS, ARCPAC) and satellite (AIRS) observations of carbon monoxide, Atmos. Chem. Phys., 10, 977-996, doi:10.5194/acp10-977-2010, 2010.

Fu, T.-M., Jacob, D. J., Palmer, P. I., Chance, K., Wang, Y. X., Barletta, B., Blake, D. R., Stanton, J. C., and Pilling, M. J.: Space-based formaldehyde measurements as constraints on volatile organic compound emissions in east and south Asia and implications for ozone, J. Geophys. Res., 112, D06312, doi:10.1029/2006JD007853, 2007

Gogoi, M. M., Suresh Babu, S., Krishna Moorthy, K., Manoj, M. R., and Jai Prakash Chaubey: Absorption characteristics of aerosols over the northwestern region of India: Distinct seasonal signatures of biomass burning aerosols and mineral dust, Atmos. Environ., 73, 92-102, 2013.

Hains, J. C., Boersma, K. F., Kroon, M., Dirksen, R. J., Cohen, R. C., Perring, A. E., Bucsela, E., Volten, H., Swart, D. P. J., Richter, A., Wittrock, F., Schoenhardt, A., Wagner, T., Ibrahim, O. W., van Roozendael, M., Pinardi, G., Gleason, J. F., Veefkind, J. P., and Levelt, P.: Testing and improving OMI DOMINO tropospheric $\mathrm{NO}_{2}$ using observations from the DANDELIONS and 
INTEX-B validation campaigns, J. Geophys. Res.-Atmos., 115, D05301, doi:10.1029/2009JD012399, 2010.

Haywood, J. M., Osborne, S. R., Francis, P. N., Keil, A., Formenti, P., Andreae, M. O., and Kaye, P. H.: The mean physical and optical properties of regional haze dominated by biomass burning aerosol measured from the C-130 aircraft during SAFARI 2000, J. Geophys. Res., 108, 8473, doi:10.1029/2002JD002226, 2003.

Haywood, J. M., Pelon, J., Formenti, P., Bharmal, N., Brooks, M., Capes, G., Chazette, P., Chou, C., Christopher, S., Coe, H., Cuesta, J., Derimian, Y., Desboeufs, K., Greed, G., Harrison, M., Heese, B., Highwood, E. J., Johnson, B., Mallet, M., Marticorena, B., Marsham, J., Milton, S., Myhre, G., Osborne, S. R., Parker, D. J., Rajot, J., Schulz, M., Slingo, A., Tanre, D., and Tulet, P.: Overview of the Dust and Biomass-burning Experiment and African Monsoon Multidisciplinary Analysis Special Observing Period-0, J. Geophys. Res.-Atmos., 113, D00C17, doi:10.1029/2008JD010077, 2008.

Heckel, A., Kim, S.-W., Frost, G. J., Richter, A., Trainer, M., and Burrows, J. P.: Influence of low spatial resolution a priori data on tropospheric $\mathrm{NO}_{2}$ satellite retrievals, Atmos. Meas. Tech., 4, 1805-1820, doi:10.5194/amt-4-1805-2011, 2011.

Herron-Thorpe, F. L., Lamb, B. K., Mount, G. H., and Vaughan, J. K.: Evaluation of a regional air quality forecast model for tropospheric $\mathrm{NO}_{2}$ columns using the OMI/Aura satellite tropospheric $\mathrm{NO}_{2}$ product, Atmos. Chem. Phys., 10, 8839-8854, doi:10.5194/acp-10-8839-2010, 2010.

Irie, H., Boersma, K. F., Kanaya, Y., Takashima, H., Pan, X., and Wang, Z. F.: Quantitative bias estimates for tropospheric $\mathrm{NO}_{2}$ columns retrieved from SCIAMACHY, OMI, and GOME-2 using a common standard for East Asia, Atmos. Meas. Tech., 5, 2403-2411, doi:10.5194/amt-5-2403-2012, 2012.

IPCC (Intergovernmental Panel on Climate Change): Couplings between changes in the climate system and biogeochemistry, in: Climate Change 2007: The Physical Science Basis. Contribution of Working Group I to the Fourth Assessment Report of the Intergovernmental Panel on Climate Change, edited by: Solomon, S., Qin, D., Manning, M., Chen, Z., Marquis, M., Averyt, K. B., Tignor, M., and Miller, H. L., 499-587, Cambridge Univ. Press, Cambridge, New York, 2007.

Jacob, D. J., Crawford, J. H., Maring, H., Clarke, A. D., Dibb, J. E., Emmons, L. K., Ferrare, R. A., Hostetler, C. A., Russell, P. B., Singh, H. B., Thompson, A. M., Shaw, G. E., McCauley, E., Pederson, J. R., and Fisher, J. A.: The Arctic Research of the Composition of the Troposphere from Aircraft and Satellites (ARCTAS) mission: design, execution, and first results, Atmos. Chem. Phys., 10, 5191-5212, doi:10.5194/acp-10-5191-2010, 2010.

Johnson, B. T., Heese, B., McFarlane, S. A., Chazette, P., Jones, A., and Bellouin, N.: Vertical distribution and radiative effects of mineral dust and biomass burning aerosol over West Africa during DABEX, J. Geophys. Res.-Atmos., 113, D00C12, doi:10.1029/2008JD009848, 2008a.

Johnson, B. T., Osborne, S. R., Haywood, J. M., and Harrison, M. A. J.: Aircraft measurements of biomass burning aerosol over West Africa during DABEX, J. Geophys. Res.-Atmos., 113, D00C06, doi:10.1029/2007JD009451, 2008b.

Jury, M. R. and Winter, A.: Warming of an elevated layer over the Caribbean, Climatic Change, 99, 247-259, doi:10.1007/s10584009-9658-3, 2010.
Kleipool, Q. L., Dobber, M. R., de Haan, J. F., and Levelt, P. F.: Earth surface reflectance climatology from 3 years of OMI data, J. Geophys. Res.-Atmos., 113, D18308, doi:10.1029/2008JD010290, 2008.

Lamsal, L. N., Martin, R. V., van Donkelaar, A., Steinbacher, M., Celarier, E. A., Bucsela, E., Dunlea, E. J., and Pinto, J.: Groundlevel nitrogen dioxide concentrations inferred from the satelliteborne Ozone Monitoring Instrument, J. Geophys. Res., 113, D16308, doi:10.1029/2007JD009235, 2008.

Lamsal, L. N., Martin, R. V., Padmanabhan, A., van Donkelaar, A., Zhang, Q., Sioris, C. E., Chance, K., Kurosu, T. P., and Newchurch, M. J.: Application of satellite observations for timely updates to global anthropogenic $\mathrm{NO}_{\mathrm{x}}$ emission inventories, Geophys. Res. Lett., 38, L05810, doi:10.1029/2010GL046476, 2011.

Leitão, J., Richter, A., Vrekoussis, M., Kokhanovsky, A., Zhang, Q. J., Beekmann, M., and Burrows, J. P.: On the improvement of $\mathrm{NO}_{2}$ satellite retrievals - aerosol impact on the airmass factors, Atmos. Meas. Tech., 3, 475-493, doi:10.5194/amt-3-475-2010, 2010.

Logan, J. A.: Nitrogen oxides in the troposphere: Global and regional budgets, J. Geophys. Res., 88, 10785-10807, doi:10.1029/JC088iC15p10785, 1983

Ma, J. Z., Beirle, S., Jin, J. L., Shaiganfar, R., Yan, P., and Wagner, T.: Tropospheric $\mathrm{NO}_{2}$ vertical column densities over Beijing: results of the first three years of ground-based MAX-DOAS measurements (2008-2011) and satellite validation, Atmos. Chem. Phys., 13, 1547-1567, doi:10.5194/acp-13-1547-2013, 2013.

Mao, J., Jacob, D. J., Evans, M. J., Olson, J. R., Ren, X., Brune, W. H., Clair, J. M. St., Crounse, J. D., Spencer, K. M., Beaver, M. R., Wennberg, P. O., Cubison, M. J., Jimenez, J. L., Fried, A., Weibring, P., Walega, J. G., Hall, S. R., Weinheimer, A. J., Cohen, R. C., Chen, G., Crawford, J. H., McNaughton, C., Clarke, A. D., Jaeglé, L., Fisher, J. A., Yantosca, R. M., Le Sager, P., and Carouge, $\mathrm{C}$. .: Chemistry of hydrogen oxide radicals $\left(\mathrm{HO}_{\mathrm{x}}\right)$ in the Arctic troposphere in spring, Atmos. Chem. Phys., 10, 58235838, doi:10.5194/acp-10-5823-2010, 2010.

Martin, R., Chance, K., Jacob, D., Kurosu, T., Spurr, R., Bucsela, E., Gleason, J., Palmer, P., Bey, I., Fiore, A., Li, Q., Yantosca, R., and Koelemeijer, R.: An improved retrieval of tropospheric nitrogen dioxide from GOME, J. Geophys. Res.-Atmos., 107, 4437, doi:10.1029/2001JD001027, 2002.

Martin, R., Jacob, D., Chance, K., Kurosu, T., Palmer, P., and Evans, M.: Global inventory of nitrogen oxide emissions constrained by space-based observations of $\mathrm{NO}_{2}$ columns, J. Geophys. Res.Atmos., 108, 4537, doi:10.1029/2003JD003453, 2003.

Mebust, A. K. and Cohen, R. C.: Observations of a seasonal cycle in $\mathrm{NO}_{\mathrm{x}}$ emissions from fires in African woody savannas, Geophys. Res. Lett., 40, 1451-1455, doi:10.1002/grl.50343, 2013.

Mebust, A. K., Russell, A. R., Hudman, R. C., Valin, L. C., and Cohen, R. C.: Characterization of wildfire $\mathrm{NO}_{\mathrm{x}}$ emissions using MODIS fire radiative power and OMI tropospheric $\mathrm{NO}_{2}$ columns, Atmos. Chem. Phys., 11, 5839-5851, doi:10.5194/acp11-5839-2011, 2011.

Miyazaki, K., Eskes, H. J., and Sudo, K.: Global $\mathrm{NO}_{\mathrm{x}}$ emission estimates derived from an assimilation of OMI tropospheric $\mathrm{NO}_{2}$ columns, Atmos. Chem. Phys., 12, 2263-2288, doi:10.5194/acp12-2263-2012, 2012. 
Moteki, N. and Kondo, Y.: Method to measure time-dependent scattering cross sections of particles evaporating in a laser beam, J. Aerosol Sci., 39, 348-364, 2008.

Moteki, N., Kondo, Y., Miyazaki, Y., Takegawa, N., Komazaki, Y., Kurata, G., Shirai, T., Blake, D. R., Miyakawa, T., and Koike, M.: Evolution of mixing state of black carbon particles: Aircraft measurements over the western Pacific in March 2004, Geophys. Res. Lett., 34, L11803, doi:10.1029/2006GL028943, 2007.

Oetjen, H., Baidar, S., Krotkov, N. A., Lamsal, L. N., Lechner, M., and Volkamer, R.: Airborne MAX-DOAS measurements over California: Testing the NASA OMI tropospheric $\mathrm{NO}_{2}$ product, J. Geophys. Res.-Atmos., 118, 7400-7413, doi:10.1002/jgrd.50550, 2013.

Osborne, S. R., Johnson, B. T., Haywood, J. M., Baran, A. J., Harrison, M. A. J., and McConnell, C. L.: Physical and optical properties of mineral dust aerosol during the Dust and Biomassburning Experiment, J. Geophys. Res.-Atmos., 113, D00C03, doi:10.1029/2007JD009551, 2008.

Palmer, P., Jacob, D., Chance, K., Martin, R., Spurr, R., Kurosu, T., Bey, I., Yantosca, R., Fiore, A., and Li, Q.: Air mass factor formulation for spectroscopic measurements from satellites: Application to formaldehyde retrievals from the Global Ozone Monitoring Experiment, J. Geophys. Res.-Atmos., 106, 1453914550, doi:10.1029/2000JD900772, 2001.

Park, R., Jacob, D., Palmer, P., Clarke, A., Weber, R., Zondlo, M., Eisele, F., Bandy, A., Thornton, D., Sachse, G., and Bond, T.: Export efficiency of black carbon aerosol in continental outflow: Global implications, J. Geophys. Res.-Atmos., 110, D11205, doi:10.1029/2004JD005432, 2005.

Parrington, M., Palmer, P. I., Lewis, A. C., Lee, J. D., Rickard, A. R., Di Carlo, P., Taylor, J. W., Hopkins, J. R., Punjabi, S., Oram, D. E., Forster, G., Aruffo, E., Moller, S. J., Bauguitte, S. J.-B., Allan, J. D., Coe, H., and Leigh, R. J.: Ozone photochemistry in boreal biomass burning plumes, Atmos. Chem. Phys., 13, 73217341, doi:10.5194/acp-13-7321-2013, 2013.

Redelsperger, J., Thorncroft, C. D., Diedhiou, A., Lebel, T., Parker, D. J., and Polcher, J.: African monsoon multidisciplinary analysis - An international research project and field campaign, B. Am. Meteorol. Soc., 87, 1739-1746, doi:10.1175/BAMS-87-121739, 2006.

Reid, J. S., Eck, T. F., Christopher, S. A., Koppmann, R., Dubovik, O., Eleuterio, D. P., Holben, B. N., Reid, E. A., and Zhang, J.: A review of biomass burning emissions part III: intensive optical properties of biomass burning particles, Atmos. Chem. Phys., 5, 827-849, doi:10.5194/acp-5-827-2005, 2005.

Reid, J. S., Hyer, E. J., Prins, E. M., Westphal, D. L., Zhang, J., Wang, J., Christopher, S. A., Curtis, C. A., Schmidt, C. C., Eleuterio, D. P., Richardson, K. A., and Hoffman, J. P.: Global Monitoring and Forecasting of Biomass-Burning Smoke: Description of and Lessons From the Fire Locating and Modeling of Burning Emissions (FLAMBE) Program, IEEE J. Sel. Top. Appl., 2, 144-162, doi:10.1109/JSTARS.2009.2027443, 2009.
Richter, A. and Burrows, J.: Tropospheric $\mathrm{NO}_{2}$ from GOME measurements, Remote Sensing of Trace Constituents in the Lower Stratosphere, Troposphere and the Earth's Surface: Global Observations, Air Poll. Atmos. Correct., 29, 1673-1683, doi:10.1016/S0273-1177(02)00100-X, 2002.

Rivera, C., Stremme, W., and Grutter, M.: Nitrogen dioxide DOAS measurements from ground and space: comparison of zenith scattered sunlight ground-based measurements and OMI data in Central Mexico, Atmosfera 26, 401-414, 2013.

Russell, A. R., Perring, A. E., Valin, L. C., Bucsela, E. J., Browne, E. C., Wooldridge, P. J., and Cohen, R. C.: A high spatial resolution retrieval of $\mathrm{NO}_{2}$ column densities from OMI: method and evaluation, Atmos. Chem. Phys., 11, 8543-8554, doi:10.5194/acp-11-8543-2011, 2011.

Singh, H. B., Anderson, B. E., Brune, W. H., Cai, C., Cohen, R. C., Crawford, J. H., Cubison, M. J., Czech, E. P., Emmons, L., Fuelberg, H. E., Huey, G., Jacob, D. J., Jimenez, J. L., Kaduwela, A., Kondo, Y., Mao, J., Olson, J. R., Sachse, G. W., Vay, S. A., Weinheimer, A., Wennberg, P. O., Wisthaler, A., and ARCTAS Sci Team: Pollution influences on atmospheric composition and chemistry at high northern latitudes: Boreal and California forest fire emissions, Atmos. Environ., 44, 4553-4564, doi:10.1016/j.atmosenv.2010.08.026, 2010.

Spurr, R.: Simultaneous derivation of intensities and weighting functions in a general pseudo-spherical discrete ordinate radiative transfer treatment, J. Quant. Spectrosc. Ra., 75, 129-175, doi:10.1016/S0022-4073(01)00245-X, 2002.

Spurr, R., Kurosu, T., and Chance, K.: A linearized discrete ordinate radiative transfer model for atmospheric remotesensing retrieval, J. Quant. Spectrosc. Ra., 68, 689-735, doi:10.1016/S0022-4073(00)00055-8, 2001.

Wiedinmyer, C., Tie, X., Guenther, A., Neilson, R., and Granier, C.: Future changes in biogenic isoprene emissions: how might they affect regional and global atmospheric chemistry?, Earth Interact., 10, 1-19, 2006.

Zhou, Y., Brunner, D., Boersma, K. F., Dirksen, R., and Wang, P.: An improved tropospheric $\mathrm{NO}_{2}$ retrieval for OMI observations in the vicinity of mountainous terrain, Atmos. Meas. Tech., 2, 401-416, doi:10.5194/amt-2-401-2009, 2009.

Zyrichidou, I., Koukouli, M. E., Balis, D. S., Kioutsioukis, I., Poupkou, A., Katragkou, E., Melas, D., Boersma, K. F., and van Roozendael, M.: Evaluation of high resolution simulated and OMI retrieved tropospheric $\mathrm{NO}_{2}$ column densities over Southeastern Europe, Atmos. Res., 122, 55-66, 2013. 